Arq. Bras. Med. Vet. Zootec., v.66, n.3, p.801-808, 2014

\title{
Occurrence of Aviadenovirus in chickens from the poultry industry of Minas Gerais
}

\author{
[Ocorrência de Aviadenovirus em aves da industria avícola de Minas Gerais] \\ C.G. Pereira ${ }^{1}$, S.Y. Marin ${ }^{1}$, B.M. Santos ${ }^{2}$, J.S. Resende ${ }^{1}$, M. Resende ${ }^{1}$, \\ A.M. Gomes ${ }^{1}$, N.R.S. Martins ${ }^{1 *}$ \\ ${ }^{1}$ Escola de Veterinária - Universidade Federal de Minas Gerais - Belo Horizonte, MG \\ ${ }^{2}$ Universidade Federal de Viçosa - Viçosa, MG
}

\begin{abstract}
The occurrence of Aviadenovirus (FAdV) was investigated in chickens from the poultry industry of Minas Gerais state, Brazil. The investigation was conducted due to the scarcity of recent data in the country and its description in neighboring countries. For this purpose, livers were collected from layer chicks $(n=25)$, older layers $(n=25)$, broilers $(n=300)$, and livers $(n=25)$ and stool $(n=25)$ samples from broiler breeders, representing the major poultry regions of the state. FAdV DNA was demonstrated using a previously described PCR protocol for amplifying part of the hexon gene encoding sequence. FAdV was found in layer chicks $(36 \%)$, widespread (100\%) in older layers, and with regional differences in broilers (24-86\%). Although all broiler breeder stools were negative, FAdV DNA was detected in livers $(16 \%, 4 / 25)$ of stool-negative birds. In order to obtain additional information on the circulation of the infection, livers of subsistence chickens collected from one poultry intensive region, were evaluated $(n=$ 12), with FAdV being detected in all samples. FAdV was found in young and old layers, broilers, broiler breeders and free-range chickens, and results suggest the circulation of FAdV among different types of chickens. The detection in older layer chickens may indicate an extended risk of horizontal transmission in regions of Minas Gerais with mixed activity of egg and meat type chickens and poor biosecurity strategies. The infection in breeders may indicate vertical transmission and the continuous production of infected progenies. The hexon-gene-targeted PCR amplicon sequences aligned with FAdV of species D of Aviadenovirus. Results indicate the necessity for biosecurity, especially for breeders, separating flocks according to origin, age and health status, which will be an advantage regarding any pathogen.
\end{abstract}

Keywords: Aviadenovirus, FAdV, layer chicken, broiler chicken, broiler breeder

\section{RESUMO}

Descreve-se a ocorrência de Aviadenovirus (FAdV) na avicultura mineira. Foram amostrados fígados de poedeiras jovens $(n=25)$ e velhas $(n=25)$ e de frangos de corte $(n=300)$. Em matrizes pesadas foram amostrados fígados $(n=25)$ e fezes $(n=25)$. O estudo envolveu as principais regióes avícolas do Estado de Minas Gerais. O DNA de FAdV foi pesquisado por PCR universal, descrito para a amplificação do gene que codifica o hexon de Aviadenovirus, usando FAdV Phelps como referência. Foi demonstrada a presença do DNA de FAdV em 100\% (25/25) das poedeiras velhas (78 semanas de idade) e em $36 \%$ (9/25) das jovens (18 dias). Em frangos de corte, a detecção variou entre 24 e $86 \%$. Embora as fezes das matrizes tenham sido negativas, foi obtido o amplicon específico em 4/25 dos fígados dessas mesmas aves, indicando menor sensibilidade para detecção nas fezes. Em amostras da avicultura familiar (fígado), colhidas de uma das regiões de avicultura intensificada, foi detectado o genoma de FAdV em $100 \%$ das galinhas $(n=12)$. A constatação de alta disseminação de FAdV em aves da avicultura industrial e familiar de Minas Gerais contribui para o entendimento da epidemiologia de Aviadenovirus. As sequências nucleotídicas dos produtos de PCR alinharam com FAdV da espécie D de Aviadenovirus. A demonstração de FAdV em reprodutores indica risco de transmissão vertical e reforça a necessidade

Recebido em 2 de julho de 2012

Aceito em 21 de outubro de 2013

*Autor para correspondência (corresponding author)

E-mail: nrsmart@gmail.com 
de biosseguridade estrita nesses plantéis. A presença de FAdV em diversos setores avícolas, incluindo poedeiras comerciais, frangos de corte, reprodutores e galinhas da avicultura familiar, recomenda a biosseguridade estrita entre as criações de mesmo tipo e de tipos diferentes de aves. A detecção em matrizes pode indicar a continuada geração de progênies infectadas.

Palavras-chave: Aviadenovirus, FAdV, galinha poedeira, frango de corte, matriz de frango de corte

\section{INTRODUCTION}

Aviadenovirus are members of Adenoviridade genus which includes seven adenovirus geese and hawk virus species designated A, B, C, D and E. In Gallus gallus domesticus, the prototype is FAdV (Fowl Adenovirus type 1), and may further be characterized into 13 serotypes (International...,). Adenoviruses have worldwide distribution and appear to be ubiquitous in the poultry population (Adair and Fitzgerald, 2008). A feature of the FAdV epidemiology is the unusually large number of serotypes that can be isolated on a farm. It is not uncommon to isolate two or more serotypes from the same bird (Hess et al., 1999), suggesting that there is little cross-protection among serotypes (Adair and Fitzgerald, 2008).

Although many diseases are associated with FAdV infection, there are conflicting evidences regarding its role as the primary etiology under field conditions. Some publications demonstrate a role for FAdV as the primary agent (Gomis et al., 2006). On the other hand, other studies consider FAdV mostly as a secondary pathogen, with pathogenesis resulting from a combined infection with immunosuppressive agents, such as chicken anemia virus (CAV) (Toro et al., 2000) or mycotoxins (Singh et al., 1996). Differences in results may be based on differences in virulence among isolates of the same or different serotype (McFerran and Smyth, 2000), as well as the differences in chicken susceptibility (Roy et al., 2004).

At present, classic inclusion body hepatitis (IBH) by FAdV is only seen as a sporadic disease. However, recent outbreaks have occurred, and although the gross lesions are similar to classical IBH, mortalities are more expressive. A more recent important pathological condition associated with FAdV is hepatitis/ hydropericardium syndrome (HHS), causing expressive economic impact in intensive poultry production in some areas of the world. This is an important disease, previously unknown in the poultry industry, which primarily affects broiler chickens at 3-6 weeks of age and is characterized by sudden onset and high mortality (Abdul-Aziz and Hasan, 1995). A FAdV investigation in 28 poultry vaccines, 26 live and 2 inactivated, was published recently (Barrios et al., 2011), and found FAdV DNA in live vaccines, produced in Jan/1991, May/1992 (Newcastle disease) and Jan/1994 (avian encephalomyelitis), all by the same manufacturer.

The polymerase chain reaction (PCR) is a molecular tool that allows highly specific and sensitive detection of the FAdV genome (Xie et al., 1999; Meulemans et al., 2001; Singh et al., 2002), with cost-benefit advantages against the traditional routine diagnostic tests.

This study aims to provide updated information on the occurrence of FAdV in the industrial chickens in the State of Minas Gerais, including a preliminary evaluation of backyard poultry.

\section{MATERIALS AND METHODS}

The study was conducted in the Avian Diseases Laboratory of the Veterinary College at the Federal University of Minas Gerais, Brazil, from 2009 to 2011. Industrial broiler chicken livers $(n=300)$ were sampled at the processing plant representing each of six different broiler slaughterhouses in the state of Minas Gerais. Broiler breeder livers $(n=25)$ and stools $(n=25)$ were collected at the end of the breeding season and progeny chicks at 18 days of age $(n=25)$. A preliminary study of family chickens $(n=12)$ was conducted on livers collected at random from semi-intensive systems, with eight samples from one farm and four from another, both located at proximity to the poultry industry farm. Pooled $(n=5)$ fragments of livers collected from SPF chicks (SPAFAS, Uberlândia, Brazil) were used as negative control.

DNA extraction was performed as described previously (Boom et al., 1990), using silicon 
dioxide as adsorbent. One microlitre volume containing approximately 200ng of total DNA extract was used as template for the amplification of part of the Aviadenovirus genome. The FAdV-1 Phelps strain (kindly provided by Dr. Jane K.A. Cook) was used as positive control in each reaction, originally replicated in SPF chicken livers. Primers F 5'(CAA GTT CAG GCA GAC GGT)-3' (Hexon A) and R 5'- (TAG TGA TGC CGC GAC ATC AT)-3' (Hexon B) and reaction protocols were as described previously (Meulemans et al., 2001) for amplifying the Aviadenovirus hexon protein coding gene sequence, including the L1 loop region (897 bp). The evolutionary relationships of Aviadenovirus sequences were inferred using the Neighbor-Joining method (Saitou and Nei, 1987) and a bootstrap consensus tree was inferred from 1000 replicates (Felsenstein, 1985) representing the evolutionary history of the Aviadenovirus sequences analyzed (Felsenstein, 1985). The evolutionary distances were computed using the Maximum Composite Likelihood method (Tamura et al., 2004). The differences in the composition bias among sequences were considered in evolutionary comparisons (Tamura and Kumar, 2002). The evolutionary analyses were conducted in MEGA5 (Tamura et al., 2011).

\section{RESULTS AND DISCUSSION}

FAdV Phelps strain control and field positive samples presented a PCR amplified 897 basepair fragment product (Fig. 1), as visualized on agarose gel electrophoresis under ultraviolet light (Meulemans et al., 2001). No detection was obtained from the SPF chicks. Using these primers, FAdV would be detected by PCR regardless of serotype (Meulemans et al., 2001). The PCR protocol used in this study enabled the detection of the target genomic segment in the total DNA diluted up to $10^{-9}$ on the positive FAdV Phelps strain used as control. The presence of FAdV DNA varied widely among flocks of the same and different production purposes (Table 1). High sensitivity allowed the detection of the viral DNA genome directly from the total DNA of field samples, without the need for virus replication in cell culture. The high sensitivity may be important in the diagnosis of subclinical or latent infections, since FAdV DNA was detected in the liver of clinically normal chickens. However, FAdV DNA was not detectable in stool samples of liver positive chickens, possibly due to the low rate of infection in clinically normal chickens (Toro et $a l, 2000)$ or DNA degradation.

The highest proportion of FAdV DNA detection $(25 / 25)$ was found in the oldest laying hens $(78$ weeks of age), by the end of the production cycle, whereas in 18 day-old layer chicks detection was the lowest (9/25), indicating horizontal infection of flocks in densely populated regions. It is assumed that a lower percentage of chicks would be produced with vertical infection from infected breeders and a progressive horizontal transmission would occur in the farm during the egg production year.

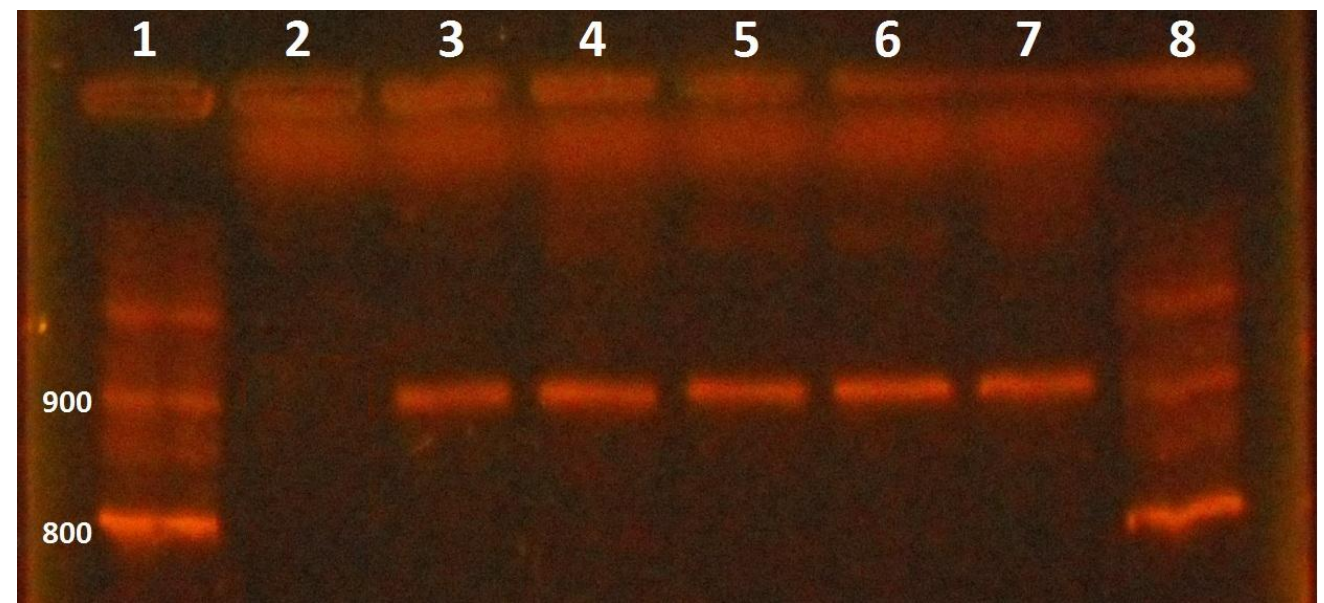

Figure 1. Electrophoresis of Aviadenovirus PCR products (897 bp). Column 1 and 8: 100 bp DNA marker; column 2: SPF chick liver negative control; column 3: FAdV Phelps strain. Columns 4 to 7 : FAdV field samples. 
Table 1. Fowl Aviadenovirus (FAdV) DNA detection (PCR) ${ }^{*}$ in chickens of the poultry industry in Minas Gerais according to production purposes

\begin{tabular}{lcccc}
\multicolumn{1}{c}{ Production purpose } & Age/days & Organ & Positive/total & Percentage \\
\hline Broiler breeder & 336 & Liver & $4 / 25$ & $16 \%$ \\
Broiler breeder & 434 & Feces & $0 / 25$ & $0 \%$ \\
Layer & 18 & Liver & $9 / 25$ & $36 \%$ \\
Layer & 546 & Liver & $25 / 25$ & $100 \%$ \\
Broiler flock 1 & 42 & Liver & $30 / 50$ & $66 \%$ \\
Broiler flock 2 & 47 & Liver & $43 / 50$ & $86 \%$ \\
Broiler flock 3 & 44 & Liver & $36 / 50$ & $72 \%$ \\
Broiler flock 4 & 44 & Liver & $12 / 50$ & $24 \%$ \\
Broiler flock 5 & 42 & Liver & $35 / 50$ & $70 \%$ \\
Broiler flock 6 & 39 & Liver & $39 / 50$ & $78 \%$ \\
\hline
\end{tabular}

Aviadenovirus universal PCR for a 897 bp product (Meulemans et al., 2001).

Management practices would have an important role for the horizontal transmission, including proximity and multi-age flocks, high population density, poor hygiene, among others, all predisposing factors that contribute to the perpetuation and spread of infectious agents. The lower rate of detection in chicks may also be associated to maternal neutralizing antibodies, not evaluated here, possibly present in significant titers during the first weeks of life, temporarily protecting from viral reactivation (McFerran and Smyth, 2000). On the other hand, the immune response is species and serotype specific (Adair and Fitzgerald, 2008), not being cross-protective, enabling multiple and consecutive infections with different serotypes, possibly justifying the different detection results, presumably depending on the specific protection status of each flock.

It was not possible to detect FAdV genome in stool samples of breeders, despite liver detection. Three hypotheses for these results are proposed, (1) low viral expression in chickens at the time of sampling, possibly located in the liver (2) fecal inhibitors (3) insufficient sampling and (4) latent infection. It is unlikely that negative results are due to lack of sensitivity of the PCR protocol in view of the high performance shown with the Phelps strain at $9 \quad \log _{10}$ dilution from experimentally infected livers. However, the possibility of low virus load in stools, below the detection limit of the test, must not be ruled out. It is also possible that the sample size was not sufficiently large for the detection of few stool positive samples.

The evolutionary relationships of the Aviadenovirus isolates PM34 and PM35 sequences obtained and the sequences of GenBank were analysed (Fig. 2). The analysis at the tree involved 21 nucleotide sequences, including the two Brazilian sequences. All positions containing gaps and missing data were eliminated and a total of 785 positions were available in the final dataset. It was very interesting to find that the alignment of the hexon-gene-targeted amplicon sequences occurred with FAdV of species D of Aviadenovirus, which includes serotypes 2, 3, 9 and 11. Results indicate that the industrial and free-range chickens evaluated in Minas Gerais were infected with Aviadenovirus D species. A sequence of serotype 11, previously detected in Brazil (Accession number FJ360747, Chacón et al., 2008; unpublished) and two strains described in Canada, 04-52447 (Accession number A7L8U1) and 05-50052-2485-O-CT (Accession number A7L8E2) (Ojkic et al., 2007; unpublished), were grouped in the same branch. 


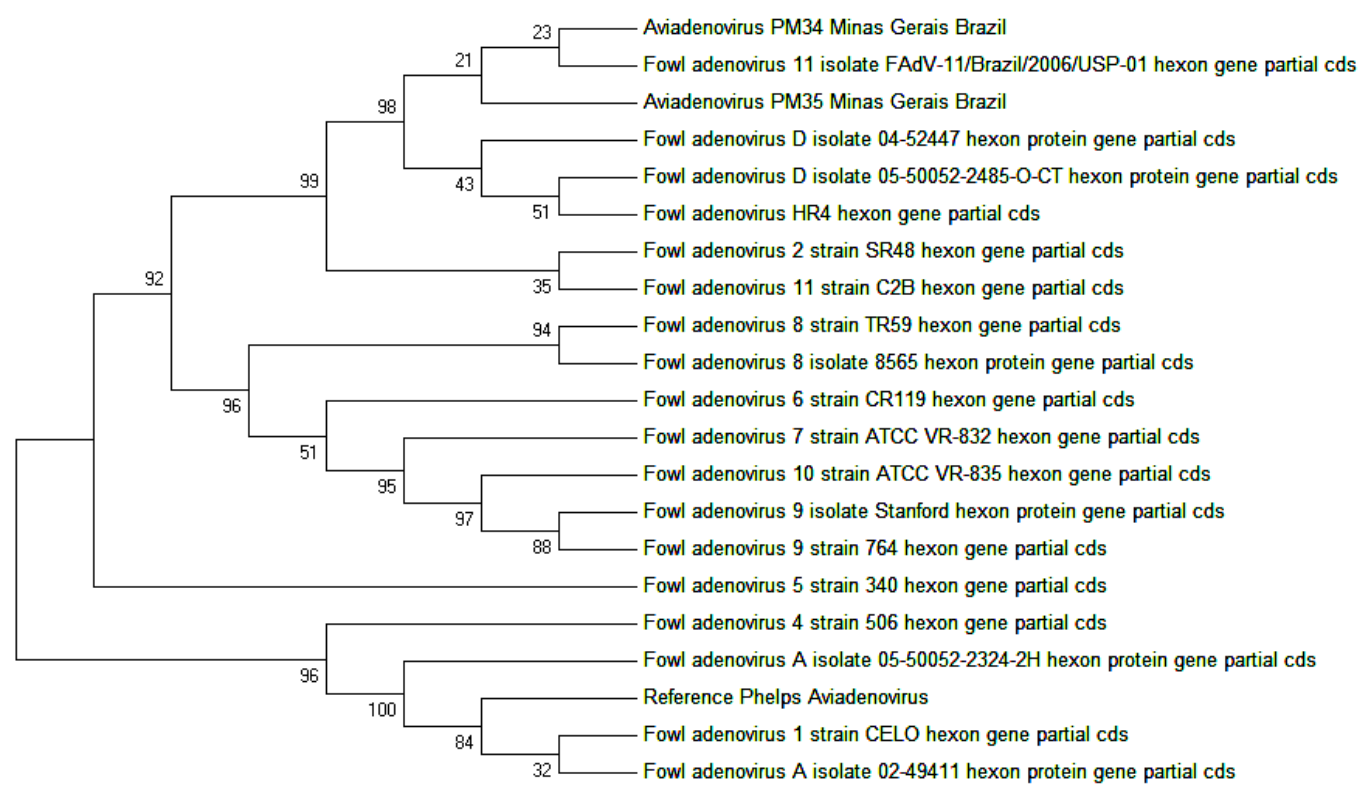

Figure 2. Evolutionary relationships of Aviadenovirus based on the hexon protein coding gene sequence including the $\mathrm{L} 1$ loop region (897 bp).

Isolates PM34 and PM35 were grouped with serotype 11 strain (São Paulo) and fowl adenovirus D strains 04-52447 and 05-50052-2485-O-CT (Ojkic et al., 2007, Canada, unpublished, submitted to EMBL/GenBank/DDBJ databases). The evolutionary history was inferred using the Neighbor-Joining method (Saitou and Nei, 1987). The bootstrap consensus tree, inferred from 1000 replicates (Felsenstein, 1985), was taken to represent the evolutionary history (Felsenstein, 1985). Branches corresponding to partitions reproduced in less than $50 \%$ bootstrap replicates are collapsed. The percentage of replicate trees in which the associated indexes clustered together in the bootstrap test $(1000$ replicates) is shown next to the branches (Felsenstein, 1985). The evolutionary distances were computed using the Maximum Composite Likelihood method (Tamura et al., 2004) and are in the units of the number of base substitutions per site. The differences in the composition bias among sequences were considered in evolutionary comparisons (Tamura and Kumar, 2002). The analysis involved 21 nucleotide sequences. All positions containing gaps and missing data were eliminated. There were a total of 785 positions in the final dataset. Evolutionary analyses were conducted in MEGA5 (Tamura et al., 2011).
The major sites for FAdV virus replication are the respiratory and digestive tract (MacFerran $e t$ al., 1977) replications which, after a period of virus excretion, may become latent, presumably due to immunity development. However, when immunity is lost, either naturally by metabolic pathways, such as during the period of peak egg production, or mediated by immunosuppressive agents, such as infectious bursal disease (IBDV) or chicken infectious anemia (CAV) viruses, the virus is reactivated and re-excretion may occur. Reactivation ensures high excretion of virus to the environment for horizontal transmission, and viremia in breeders enables vertical transmission to the next generation (McFerran and Smyth, 2000). Chicken (fowl) serotypes are considered widespread in industrial and family chickens and have been detected in turkey, pigeon, budgerigar, and mallard duck (Cho, 1976; McFerran et al., 1976). The possibility was described for the origin of chicken isolates being guinea fowl (McFerran et al., 1972) and pheasants (McFerran et al., 1976). Biosecurity remains of paramount importance not only among chickens, but also among these avian species. However, FAdV is not highly infectious and it may require a few weeks for the entire flock to be infected (Cook, 1970; van Eck et al., 1976), indicating that for the horizontal transmission it may take a longer period of failed biosecurity. However, especially with concurrent infections, the spread can be 
very quick in a flock (MacFerran and Adair, 1977), such as with CAV or IBDV.

It was interesting to notice differences for FAdV infection among broiler flocks in Minas Gerais. The detection of FAdV DNA in the liver of broilers ranged from 24 to $86 \%$ among flocks studied. However, the profile of FAdV infection in each respective parent stock is not known. It is apparent that a varied range of vertical, but also less importantly horizontal transmission is occurring for broilers, differences which may be based on breeder health standards, such as breeder age and type-specific immunity, since serotype-specific immunity may result in reduced homologous vertical transmission (Adair and Fitzgerald, 2008). Different biosecurity standards occur among broiler flocks, the horizontal infection involving a wide variety of means. Deficiency in cleaning, particularly the disinfection of houses and equipment, associated with FAdV high resistance, may allow a residual infective load that in consecutive flocks may build up to a significant challenge for the next flock. Alternative sources of infection may be the presence of other birds near the facilities. Vaccination teams may transport Aviadenovirus from farm to farm (Akhtar et al., 1992), representing the major risk factor for introducing FAdV in a farm.

In a previous study, Barrios et al. (2009) found CAV in backyard chickens in Minas Gerais, the type of chickens described here FAdV, results which suggest potential co-infection and negative repercussion to the immune system.

Barrios et al. (2011) found FAdV DNA in 3/26 live poultry vaccines produced from 1991 to 1994, but no detection in the following years up to the present. The results indicated a role for live vaccines in the epidemiology of FAdV, possibly partially related to its widespread occurrence, as detected in our results. Considering complicating factors in the epidemiology of important avian viruses, authors additionally detected avian Orthoreovirus (ARV) contaminating $7 / 26$ of vaccines examined produced by three different manufacturers. From these, five had also chicken anemia virus (CAV). In three vaccines from the same manufacturer ARV, CAV and FAdV associated contaminants were found. A triple-contaminant infection, in addition to the original live vaccine strains (Newcastle disease virus La Sota or avian encephalomyelitis Van Roekel strains), might have been of impact to the recipient susceptible flocks.

Avian Orthoreovirus was an additional cause of immunosuppression described previously in our region (Rios et al., 2012), and may complicate further the complex epidemiology of chicken viruses in the field.

FAdV exhibits high resistance to most commonly used detergents and disinfectants, allowing the virus to persist for long periods in the poultry house, easily transmitted by infected fomites (MacFerran and Adair, 1977). FAdV was shown to cause persistent infection and having intermittent elimination in infected individuals (Grgic et al., 2006, Philippe et al., 2007). This is commonly combined with a failed biosecurity management system and environmental contamination. Multiple age and origin sites increase the risk of multiple FAdV infections and heating of the virus, since birds introduced are always susceptible to infection. Repeated cycles of viral replication may cause mutations in the genome of the agent promoting the emergence of strains of different pathogenicities (Adair and Fitzgerald, 2008)

FAdV was detected in all the livers of free-range family chickens. Free-range chickens are usually collections of different origins, but also with inbred generations, and different species maintained together, facilitating the perpetuation of the infection. The possibility was suggested for all avian species being susceptible to infection (Adair and Fitzgerald, 2008). As the examined free-range chickens were raised in the region where the poultry industry is significant, lack of biosecurity may allow the escape of FAdV and other pathogens into commercial poultry. Free-range chickens FAdV status was previously unknown in Brazil, although the scientific literature had suggested widespread infection in chickens (Cho, 1976; McFerran et al., 1976). A potentially negative role for FAdV is considered on productivity and performance, most importantly taking into consideration the potential co-infections by locally studied CAV (Barrios et al., 2009), IBDV (Gomes et al., 2005) and avian Orthoreovirus (Rios et al., 2012). 


\section{CONCLUSIONS}

FAdV infection was found widespread and apparently circulates in industrial and free range poultry in Minas Gerais. Two FAdV isolate sequences encoding for the hexon protein including the L1 loop region were analyzed and strains were grouped into the D species of Aviadenovirus, together with a previously described serotype 11 in Brazil. Regarding graver repercussions of vertical infection, breeders should be monitored and strategic plans for control would be an interesting initiative. Biosecurity raised Aviadenovirus-free breeders would produce healthier progenies, although such status might not be feasible in practice. The importance of immunosuppressive agents for the pathogenicity of FAdV recommends for a common control strategy. Previous studies have shown that ARV, CAV, IBDV are very common in the region. The adoption of biosecurity holds also for the broilers, and variations in the detection rates of FAdV DNA suggest that biosecurity is not effective to prevent horizontal transmission for poultry intensive areas. The high occurrence of FAdV in industrial flocks in the state of Minas Gerais would recommend for efforts on monitoring and improving the biosecurity of breeders.

\section{ACKNOWLEDGEMENTS}

This work is part of the National Institute of Science and Technology (Instituto Nacional de Ciência e Tecnologia-INCT), Genetic and Health Information of the Brazilian Livestock (Informação Genético-Sanitária da Pecuária Brasileira-IGSPB). Authors are indebted to CNPq, FAPEMIG and FEP-MVZ for financial support.

\section{REFERENCES}

ABDUL-AZIZ, T.A.; HASAN, S.Y. Hydropericardium syndrome in broiler chickens: Its contagious nature and pathology. Res. Vet. Sci., v.59, p.219-221, 1995.

ADAIR, B.M.; FITZGERALD, S.D. Adenovirus infections. In.: Saif, Y.M. Diseases of Poultry. 12. ed. Ames, Iowa: Iowa State, 2008. p.251296.
AKHTAR, S.; ZAHID, S.; KLAN, M.I. Risk factors associated with hydropericardium syndrome in broiler flocks. Vet. Rec., v.131, p.481-482, 1992.

BARRIOS, P.R.; MARIN, S.Y.; RESENDE, M. et al. Occurrence of chicken anemia virus in backyard chickens of the metropolitan region of Belo Horizonte, Minas Gerais. Rev. Bras. Cienc. Avic., v.11, p.135-138, 2009.

BARRIOS, P.R.; MARIN, S.Y.; RIOS, R.L. et al. A retrospective PCR investigation of Avian Orthoreovirus, chicken infectious anemia and fowl Aviadenovirus genomes contamination in commercial poultry vaccines in Brazil. Arq. Bras. Med. Vet. Zootec., v.64, p.231-235, 2011.

BOOM, R.; SOL, C.; BELD, M. et al. Improved silica-guanidiniumthiocyanate DNA isolation procedure based on selective binding of bovine alpha-casein to silica particles. J. Clin. Microbiol., v.37, p.615-619, 1999.

CHO, B.R. An adenovirus from a turkey pathogenic to both chicks and turkey poults. Avian Dis., v.20, p.714-723, 1976.

COOK, J.K.A. Incidence of chick embryo lethal orphan virus antibody in the fowl (Gallus domesticus) in Britain. Res. Vet. Sci., v.11, p.343-348, 1970.

FELSENSTEIN, J. Confidence limits on phylogenies: An approach using the bootstrap. Evolution, v.39, p.783-791, 1985.

GOMES, A.D.; ABREU, J.T.; REDONDO, R.A.F. et al. Genotyping of infectious bursal disease virus strains by restriction fragment length polymorphism analysis of the VP1, VP2, and VP3 genes. Avian Dis., v.49, p.500-506, 2005.

GOMIS, S.; GOODHOPE, R.; OJKIC, D. et al. Inclusion body hepatitis as a primary disease in broilers in Saskatchewan, Canada. Avian Dis., v.50, p.550-555, 2006.

GRGÍC, H.; PHILIPPE, C.; OJKÍC, D. et al. Study of vertical transmission of fowl adenoviruses. Can. J. Vet. Res., v.70, p.230-233, 2006.

HESS, M.; RAUE, R.; PRUSAS, C. Epidemiological studies on fowl adenoviruses isolated from cases of infectious hydropericardium. Avian Pathol., v.28, p.433439, 1999. 
INTERNATIONAL Committee on Taxonomy of Viruses (ICTV). VIRUS taxonomy Disponível em: http://www.ictvonline.org/index.asp?bhcp=1. Acessado em: 18/12/2010

McFERRAN, J.B.; CLARKE, J.K.; CONNOR, T.J. Serological classification of avian adenoviruses. Arch Gesamte Virusforsch, v.39, p.132-139, 1972.

McFERRAN, J.B.; CONNOR, T.J.; McCRACKEN, R.M. Isolation of adenoviruses and reoviruses from avian species other than domestic fowl. Avian Dis., v.20, p.519-524, 1976.

McFERRAN, J.B.; SMYTH, J.A. Avian Adenovirus. Rev. Sci. Tech. Off. Int. Epiz., v.19, p.589-601, 2000.

MEULEMANS, G.; BOSCHMANS, M.; BERG, T.P. et al. Polymerase chain reaction combined with restriction enzyme analysis for detection and differentiation of fowl adenovirus. Avian Pathol., v.30, p.655-660, 2001.

OJKIC, D.; MARTIN, E.; SWINTON, J. et al. Genotyping of Canadian isolates of Fowl adenoviruses. (unpublished). Submitted to the EMBL/GenBank/DDBJ databases, 2007.

PHILIPPE, C.; GRGIC, H.; OJKIÆ, D. et al. Serologic monitoring of a broiler breeder flock previously affected by inclusion body hepatitis and testing of the progeny for vertical transmission of fowl adenoviruses. Can. J. Vet. Res., v.71, p.98-102, 2007.

RIOS, R.L.; MARÍN, S.Y.; GOMES, A.M. et al. The occurrence of Orthoreovirus, Rotavirus and chicken anemia virus in chickens of the poultry industry in Minas Gerais, Brazil. Arq. Bras. Med. Vet. Zootec., v.64, p.1613-1620, 2012.

ROY, P.; MURALIMANOHAR, B.; KOTEESWARAN, A. et al. Experimental studies on hydropericardium syndrome in two different synthetic lines of broiler chickens. Vet. Archiv., v.74, p.157-164, 2004.

SAITOU, N.; NEI, M. The neighbor-joining method: A new method for reconstructing phylogenetic trees. Mol. Biol. Evolut., v.4, p.406425, 1987.
SINGH, A.; OBEROI, M.S.; GREWAL, G.S. et al. The use of PCR combined with restriction enzyme analysis to characterize fowl adenovirus field isolates from northern India. Vet. Res. Comm., v.26, p.577-585, 2002.

SINGH, A.; OBEROI, M.S.; JAND, S.K. et al. Epidemiology of inclusion body hepatitis in poultry in northern India from 1990 to 1994. Rev, sci. tech. Off. Int. Epiz., v.15, p.1053-1060, 1996.

TAMURA, K., NEI, M., KUMAR, S. Prospects for inferring very large phylogenies by using the neighbor-joining method. Procee. of the Nat. Academy of Sci. (USA), v.101, p.11030-11035, 2004.

TAMURA, K. AND KUMAR, S. Evolutionary distance estimation under heterogeneous substitution pattern among lineages. Mol. Biol. Evolut., v.19, p.1727-1736, 2002.

TAMURA, K.; PETERSON, D.; PETERSON, $\mathrm{N}$. et al. MEGA5: molecular evolutionary genetics analysis using maximum likelihood, evolutionary distance, and maximum parsimony methods. Mol. Biol. Evol., v.28, p.2731-2739, 2011.

TORO, H.; GONZALEZ, C.; CERDA, L. et al. Chicken anemia virus and fowl adenovirus: association to induce the inclusion body hepatitis/hydropericardium syndrome. Avian Dis., v.44, p.51-58, 2000.

VAN ECK, J.H.; DAVELAAR, HEUVELPLESMAN, T.A. et al. Dropped egg production, soft shelled and shell-less eggs associated with appearance of precipitins to adenovirus in flocks of laying fowls. Avian Pathol., v.5, p.261-272, 1976.

XIE, Z.; FADL, A.A.; GIRSHICK, T. et al. Detection of avian adenovirus by polymerase chain reaction. Avian Dis., v.43, p.98-105, 1999. 